\title{
On Effects of Macroeconomic Factors on Rate of Return on Stocks on HoChiMinh Stock Exchange
}

\author{
VÕ TH!̣ THÚY ANH \\ Đà Nẵng University of Economics \\ Email: vothuyanh@yahoo.com \\ NGUYẼ̃N THANH HẢI \\ Đà Nẵng University of Economics \\ Email: hainguyen2131@gmail.com
}

\section{ARTICLE INFO}

Article history:

Received:

May 3, 2013

Received in revised form July 22, 2013

Accepted:

Sep. 25,2013

Keywords:

factor,

Vietnamese stock market, rate of return

\begin{abstract}
Using factor model and fixed or random effect approaches, this article studies the factors affecting the rate of return on the stocks listed on the Vietnamese stock market. The results show that the rate of return is affected by the two factors: inflation and the Nikkei index as an indicator of regional economy. The impact of inflation is much more powerful. The strongest impact of the unexpected inflation is found in industrial sector and consumption while enterprises with good business performance only suffer a milder effect. The impact of Nikkei index on local stocks is rather weak but less dispersed.
\end{abstract}




\section{INTRODUCTION}

Since the first trading session of HCMC Securities Trading Center on July 28, 2000, Vietnamese stock market has made remarkable developments. Due to economic recession from 2008 up to now, however, it experienced upheavals caused by negative effects of macroeconomic factors. Studying impacts of such factors on the stock market, therefore, is crucial, especially during this global economic recession. Research results may provide policy makers and investors with data about effects of each factor, thereby helping them make right decisions and policies.

In this research, based on factor model and fixed effect model (FEM) and random effect model (REM), the authors try to estimate impact of macroeconomic factors on the rate of return on the stocks listed on the HCMC Stock Exchange (HOSE). The results show that the rate of return is affected by inflation and the Nikkei index and the impact of inflation is much stronger than that of the Nikkei index. The strongest impact of unexpected inflation is found in industrial sector and consumption while stocks of enterprises with good business performance only suffer a milder effect.

Stocks that have poor liquidity or which were once suspended, however, are free from effects of inflation. Investors, therefore, should pay full attention to effects of inflation when making investment decisions. Similarly, the government, SBV and State Securities Commission need coordination and cooperation to keep inflation under control, thereby stabilizing the stock market. Additionally, publicizing information about inflation can help reduce bad effects of unexpected inflation.

\section{THEORETICAL BASIS AND RESEARCH PROCESS}

\section{a. Theoretical Framework:}

The framework for this research is factor model introduced by Ross (1976) based on two basic hypotheses:

- Rate of return on stocks is affected by two basic groups of factors: (1) macroeconomic factors; and (2) firm-specific factors.

- Macroeconomic factors may be divided into common risk factors $F_{j}$ in which $F_{j}$ is unexpected event of macroeconomic factor $j$.

In the factor model, identification of factors affects greatly results of the model. Ross (1976), however, did not decide which and how many factors could be included in the model. The identification of factors, therefore, becomes a rather subjective and empirical issue that 
causes difficulties in application of the model. By studying previous researches by Chen Roll - Ross (1986), Kwon, Shin \& Bacon (1997), Gan, Lee, Yong \& Zhang (2006), Trần Minh Ngọc Diễm (2008); Nguyễn Thị Thu Hiền \& Đinh Thị Hồng Loan (2009) and qualitative analysis, the authors suggest the following factors that can affect prices of stocks in Vietnam:

- Inflation: Unexpected fluctuations in inflation affect greatly the prices of securities. Increased inflation is an alarming sign of the economy that may lead to loss of confidence, especially when the government fails to prevent it from increasing. High inflation rates usually cause sell-offs driven by herd instinct and trust crisis, resulting in a serious shortage of liquidity. In other words, the inflation only affects directly the stock prices in nations where the inflation fluctuates unpredictably and investors lose trust in controlling power of the government.

- Interest rate: Changes in interest rate on money market produce indirect but sensitive effect on the stock market. Increased interest rate will redirect money to banks instead of stock market and make expected rate of return from the stock market higher because investors want rate of return on stocks to be higher than return from banks. This leads to falls in stock prices.

- Exchange rate: This rate affects competitiveness of import-export firms and their stocks. Moreover, the exchange rate may affect the rate of return on stocks through its effects on flows of investments to stock markets in various countries.

If the domestic currency is expected to appreciate, the market becomes more attractive to foreign investors. On the other hand, anticipation of depreciation of domestic currency drives foreign investors away, causing bad effects on local stock market. Additionally, sudden increases in exchange rate may be considered as a poor management or ineffective policies. In this case, investors, especially foreign ones, will lose trust in local economy and government's policies and withdraw from local stock markets. However, researches by Gan, Lee, Yong \& Zhang (2006), Mohammad, Hussain Naqvi, Lal \& Zehra (2012) do not detect effects of exchange rate on stock prices.

- World gold price: Gold market also competes against stock market for investment and it has a relationship with the rate of return on stocks. Investment in gold is considered as a way to avoid risk during an economic recession. In such a period, flows of capital tend to move from stock markets to the gold ones. When signs of recovery appear, investors usually sell gold to invest in the stock market. 
Most foreign researches do not mention the world gold price as a factor. In this research, however, the authors include it in the model because Vietnamese people like buying gold, especially when they face high inflation or economic recession.

- Money supply: Changes in money in circulation supposedly affect quickly the stock market. Withdrawal of a large volume of money from circulation may impact directly on investors and reduce capital turnover and aggregate demand. Reduced sources of capital hinder investment in stocks and effects on the stock market are inevitable.

Economic development is usually measured by growth of GDP or industrial output that has a close relation with stock prices. Economic growth has remarkable effects on rate of return on stocks and the stock market in general. When investors expect a high growth rate and increases in stock prices, more investments are injected into the stock market. Contrarily, possibility of a slowdown or recession makes them pull their capital out of the stock market.

- Rates of return from international stock exchanges: Global integration makes changes in important stock indexes impact on stock prices in any country. Mukhopadhyay \& Sarkar (2003) detect effects of NASDOQ on Indian stock market. Price indexes of some major markets, moreover, also reflect situation of regional and international economies and have effects on stock prices in certain countries. In this research, the authors take into consideration three indexes: MSCI AC (All Country) Asia, American S\&P500 and Japanese Nikkei 225.

\section{b. Research Model:}

In this research we use the factor model and its variations FEM and REM with the same common risk factors.

- Factor model:

The model applied to study of effects of macroeconomic factors on fluctuations in rate of return on market portfolio or stocks is as follows:

$$
\begin{aligned}
& \mathrm{r}_{\mathrm{mt}}=\beta_{0}+\beta_{1} \mathrm{~F}_{1 \mathrm{t}}+\beta_{2} \mathrm{~F}_{2 \mathrm{t}}+\ldots \ldots . .+\beta_{\mathrm{k}} \mathrm{F}_{\mathrm{kt}}+\mathrm{u}_{\mathrm{it}}(1 \mathrm{a}) \\
& \mathrm{r}_{\mathrm{it}}=\mathrm{a}+\beta_{\mathrm{i} 1} \mathrm{~F}_{1 \mathrm{t}}+\beta_{\mathrm{i} 2} \mathrm{~F}_{2 \mathrm{t}}+\ldots \ldots \ldots+\beta_{\mathrm{ik}} \mathrm{F}_{\mathrm{kt}}+\mathrm{u}_{\mathrm{it}} \quad(1 \mathrm{~b}) \\
& \text { Where }
\end{aligned}
$$

$\mathrm{r}_{\mathrm{mt}}$ : rate of return on market portfolio in period $\mathrm{t}^{\text {th }}$;

$r_{i t}:$ rate of return on stock $i$ in period $t^{\text {th }}$;

$\mathrm{t}=1, \ldots ., \mathrm{T}$ with $\mathrm{T}$ representing number of period; and $\mathrm{i}=1, \ldots ., \mathrm{N}$ with $\mathrm{N}$ representing number of stocks. 
$\mathrm{F}_{\mathrm{kt}}$ : value of risk factor $\mathrm{k}$ period $\mathrm{t}^{\text {th. }}$

$\beta_{\mathrm{ik}}$ : sensitivity of stock i to factor $\mathrm{k}$;

$\mathrm{u}_{\mathrm{it}}$ : residual of the model considered as stock-specific risk (or firm-specific risk). $\mathrm{u}_{\mathrm{it}}$ is assumed to have no relationship with $\mathrm{u}_{\mathrm{j} t}$.

Because factors $F_{j}$ are assumed to be common risk factors and therefore if $F_{j}$ is significant in model (1a) it will be significant in model (1b) and vice versa.

- FEM and REM:

FEM and REM based on the factor model are as follows:

$$
\begin{aligned}
& \text { FEM: } R_{i t}=a_{i}+\beta_{1} F_{1 t}+\beta_{2} F_{2 t}+\ldots \ldots . .+\beta_{k} F_{k t}+u_{t} \\
& \text { REM R R }{ }_{i t}=b_{i}+\beta_{1} F_{1 t}+\beta_{2} F_{2 t}+\ldots \ldots . .+\beta_{k} F_{k t}+u_{t} \\
& b_{i}=b+v_{i}
\end{aligned}
$$

$\mathrm{R}_{\mathrm{it}}$ and $\mathrm{F}_{\mathrm{kt}}$ in those two models are the same as the ones in model (1b). All hypotheses in models (2) and (3) are not different from those in the factor model. In FEM and REM, however, impacts of factors on rate of return from stocks are similar $\left(\beta_{\mathrm{k}}\right)$ while in the factor model these impacts on rate of return for individual stock are different $\left(\beta_{\mathrm{ik}}\right)$. The model $(1 \mathrm{~b})$, in fact, is a set of equation where the number of equation is the number of stocks $(\mathrm{N})$ and $\mathrm{T}$ observations, while models (2) and (3) are an equation with panel data $\mathrm{N} \mathrm{x} \mathrm{T}$. In models (2) and (3), intercepts $a_{i}$ and $b_{i}$ are part of risk-free return and reflect features of individual stocks. In model (2) $a_{i}$ is fixed while $b_{i}$ is the model (3) is random.

\section{c. Data:}

This research employs data about macroeconomic factors mentioned in section b (Research model) and prices of stocks listed on HOSE in the years 2007-2012 (Pre-2007 data are not used because operations in the stock market before 2007 were not stable). The number of listed companies with full data needed for the research is 35 .

d. Research Process:

Step 1: Identifying factors that may affect stock prices and developing the research model based on the factor model.

Step 2: Gathering and processing data

Daily rate of return is based on adjusted closing prices of stocks as follows:

$\mathrm{R}_{\mathrm{it}}=\ln \left(\mathrm{P}_{\mathrm{it}}\right)-\ln \left(\mathrm{P}_{\mathrm{it}-1}\right)$,

where $\mathrm{P}_{\mathrm{it}}$ is the stock price and turned into monthly rate of return. 
Indexes S\&P500, Nikkei 225 and MSCI AC (All Country) Asia, VNlindex and gold prices are processed in the same method used for stock prices. As for indexes S\&P500 and MSCI AC (All Country) Asia, the authors always use data of the previous day because difference in time zone leads to different effects on local stock market.

Data about inflation, money supply, M2, and exchange rate are processed in terms of growth rate.

Risk factors are calculated from values of corresponding variables minus mean. In other words, we assume that mean of variable is expected value.

As for the Vietnamese growth rate, it is only publicized on a quarterly basis and if it is included in the model while the surveyed period is rather short, we can only gather 24 observations that are not high enough for us to estimate effects of factors. We therefore cannot include it in the model, and this becomes a major shortcoming of the research.

Step 3: Testing for multicollinearity: Model (1) is tested by OLS method while models (2) and (3) by OLS with variance adjusted. Because impacts of factors on stock prices may have some lag besides $\mathrm{F}_{\mathrm{jt}}$, lags $\mathrm{F}_{\mathrm{jt}-1}$ and $\mathrm{F}_{\mathrm{jt}-2}$ of these factors are also included in the model.

Step 4: Testing hypotheses of the linear regression model such as autocorrelation and heterogeneity of residual variance. The Durbin-Watson test is used to test for the autocorrelation, and the White test for the heteroskedasticity.

Step 5: Fisher test is used for testing overall significance of the model and t-Student test for significance of individual variables. Insignificant variables are removed from the model. In model (1b), however, variable is only removed when it has no significance in the whole set of equations, that is, it has no effect on any stocks. Steps 4 and 5 are repeated afterward.

Step 6: Choice of model: To choose between (1), (2) and (3), we perform Wald test on model (1): $\mathrm{H}_{0}: \beta_{1 \mathrm{k}}=\beta_{2 \mathrm{k}}=\ldots \ldots=\beta_{\mathrm{Nk}}$, with $\mathrm{k}=1, \ldots, \mathrm{K}$. To choose between (2) and (3), Hausman test is employed.

Step 7: Analyzing results and forming recommendations for policy makers and investors.

\section{RESEARCH RESULTS}

\section{a. Choice of Model:}


Table 1: Regression of Factor Model for VNIndex

\begin{tabular}{ccccccc}
\hline & & Inflation & \multicolumn{4}{c}{ Rate of return on Nikkei } \\
Factor & $\boldsymbol{\beta}$ & $\begin{array}{r}\text { Standard } \\
\text { deviation }\end{array}$ & Prob & $\boldsymbol{\beta}$ & $\begin{array}{l}\text { Standard } \\
\text { deviation }\end{array}$ & Prob \\
\cline { 2 - 7 } & -3.418855 & 1.274530 & 0.0091 & 0.825162 & 0.179178 & 0.0000 \\
$\mathrm{R}^{2}$ & & \multicolumn{5}{c}{0.280972} \\
\hline
\end{tabular}

Table 2: Regression of Factor Model for Individual Industries

\begin{tabular}{lcccccc}
\hline \multirow{2}{*}{$\begin{array}{c}\text { Stock } \\
\text { symbol }\end{array}$} & \multicolumn{3}{c}{ Inflation } & \multicolumn{3}{c}{ Rate of return on Nikkei } \\
\cline { 2 - 7 } Agriculture - Forestry & - Fisheries & & $\boldsymbol{\beta}$ & Standard & Prob \\
\hline ABT & -3.630976 & 1.502080 & 0.0160 & 0.736523 & 0.211168 & 0.0005 \\
AGF & -5.234166 & 1.729911 & 0.0026 & 0.676748 & 0.243197 & 0.0056 \\
FMC & -5.116092 & 1.524724 & 0.0009 & 0.671224 & 0.214351 & 0.0018 \\
LAF & -2.507886 & 2.612291 & 0.3375 & 1.140269 & 0.367246 & 0.0020 \\
NSC & -3.711566 & 1.598273 & 0.0206 & 0.648418 & 0.224691 & 0.0041 \\
SSC & -5.061065 & 1.774542 & 0.0045 & 0.861142 & 0.249472 & 0.0006 \\
TS4 & -4.765352 & 2.296732 & 0.0385 & 1.481560 & 0.322883 & 0.0000 \\
\hline Consumer goods & & & & & \\
BHS & -3.707225 & 1.355454 & 0.0064 & 0.374575 & 0.190555 & 0.0498 \\
CLC & -3.289616 & 1.282044 & 0.0105 & 0.368796 & 0.180235 & 0.0412 \\
GIL & -2.940688 & 1.64457 & 0.0742 & 0.694263 & 0.231200 & 0.0028 \\
KDC & -5.239635 & 1.823414 & 0.0042 & 1.250781 & 0.256342 & 0.0000 \\
KHA & -5.098617 & 1.945327 & 0.0090 & 0.719525 & 0.273481 & 0.0087 \\
SAV & -2.943126 & 1.810483 & 0.1045 & 0.507515 & 0.254524 & 0.0466 \\
SCD & -1.359140 & 2.186283 & 0.5344 & 0.558546 & 0.307356 & 0.0697 \\
TAC & -2.319471 & 2.230728 & 0.2988 & 0.961622 & 0.313604 & 0.0023 \\
VNM & -1.911678 & 1.291203 & 0.1392 & 0.575941 & 0.181522 & 0.0016 \\
\hline Manufacturing & & & & & \\
HBC & -5.678222 & 1.768998 & 0.0014 & 0.798422 & 0.248692 & 0.0014 \\
LBM & -5.207211 & 2.377840 & 0.0289 & 0.960473 & 0.334286 & 0.0042 \\
& & & & & & \\
SHyyyyyy
\end{tabular}




\begin{tabular}{lllllll} 
MHC & -5.670316 & 2.101002 & 0.0072 & 0.895440 & 0.295367 & 0.0025 \\
NAV & -5.532959 & 1.963691 & 0.0050 & 0.732347 & 0.276063 & 0.0082 \\
PJT & -5.547115 & 1.776466 & 0.0019 & 0.744168 & 0.249742 & 0.0030 \\
PVD & -2.506812 & 1.627564 & 0.1241 & 0.766928 & 0.228809 & 0.0009 \\
TCR & -4.211905 & 1.398906 & 0.0027 & 0.574460 & 0.196663 & 0.0036 \\
VIP & -5.932751 & 2.109618 & 0.0051 & 0.811089 & 0.296578 & 0.0064 \\
\hline Multi-industry companies & & & & & \\
COM & -2.570565 & 1.452802 & 0.0783 & 0.297926 & 0.204240 & 0.1462 \\
FPT & -6.251678 & 1.843991 & 0.0008 & 0.676661 & 0.259235 & 0.0097 \\
REE & -5.947689 & 2.303431 & 0.0105 & 0.952936 & 0.323825 & 0.0036 \\
\hline Consumer services & & & & & \\
HAX & -3.497155 & 2.043190 & 0.0885 & 0.944905 & 0.287239 & 0.0012 \\
PNC & -3.535927 & 1.954783 & 0.0719 & 0.537569 & 0.274811 & 0.0518 \\
TNA & -5.229099 & 2.107762 & 0.0139 & 0.772046 & 0.296317 & 0.0098 \\
\hline Public utility services & & & & & 0.019 \\
KHP & -4.218493 & 1.583484 & 0.0081 & 0.529029 & 0.222612 & 0.0180 \\
PGC & -6.406299 & 1.917147 & 0.0009 & 0.846224 & 0.269520 & 0.0018 \\
SFC & -5.448235 & 1.736182 & 0.0018 & 0.383773 & 0.244079 & 0.1168 \\
SJD & -4.409847 & 1.217056 & 0.0003 & 0.223135 & 0.171098 & 0.1931 \\
VSH & -3.382359 & 1.575344 & 0.0325 & 0.511135 & 0.221468 & 0.0216 \\
\hline
\end{tabular}

Results of regression of factor model for VNIndex and the stock market show that the rate of return on stocks is only affected by inflation and Nikkei index.

Table 3: Results of FEM and REM

\begin{tabular}{lcccc}
\hline \multirow{2}{*}{ Model } & \multicolumn{2}{c}{ FEM } & \multicolumn{2}{c}{ REM } \\
\cline { 2 - 5 } & \multicolumn{1}{c}{$\boldsymbol{\beta}$} & Prob & $\beta$ & Prob \\
\hline Stock market & & & & \\
Exchange rate & -0.1288949 & 0.000 & -0.1288949 & 0.000 \\
Inflation & -4.165925 & 0.000 & -4.165925 & 0.000 \\
Interest rate & -0.5255368 & 0.016 & -0.5255368 & 0.011 \\
Nikkei & 0.3910567 & 0.000 & 0.3910567 & 0.000
\end{tabular}


56 | Võ Thị Thúy Anh \& Nguyễn Thanh Hải | 48 - 61

\begin{tabular}{|c|c|c|c|c|}
\hline MSCI & 0.4738157 & 0.008 & 0.4738157 & 0.000 \\
\hline Gold & -0.1588218 & 0.000 & -0.1588218 & 0.005 \\
\hline Credit & -0.6613893 & 0.000 & -0.6613893 & 0.000 \\
\hline $\mathrm{R}^{2}$ & 0.1635 & & 0.1635 & \\
\hline \multicolumn{5}{|c|}{ Agriculture - Forestry - Fisheries } \\
\hline Inflation & -4.094905 & 0.000 & -4.287508 & 0.0000 \\
\hline MSCI & 0.4641048 & 0.097 & 0.499581 & 0.026 \\
\hline Nikkei & 0.5537017 & 0.004 & 0.5184849 & 0.000 \\
\hline Money supply & & & -0.3122379 & 0.056 \\
\hline $\mathrm{R}^{2}$ & 0.1870 & & 0.1884 & \\
\hline \multicolumn{5}{|c|}{ Consumer goods } \\
\hline Inflation & -2.980048 & 0.000 & -2.980048 & 0.000 \\
\hline Interest rate & -1.034515 & 0.016 & -1.034515 & 0.002 \\
\hline Nikkei & 0.3602898 & 0.011 & 0.3602898 & 0.001 \\
\hline MSCI & 0.3228331 & 0.037 & 0.3228331 & 0.012 \\
\hline $\mathrm{R}^{2}$ & 0.1439 & & 0.1439 & \\
\hline \multicolumn{5}{|c|}{ Manufacturing } \\
\hline Inflation & -4.703293 & 0.000 & -4.783157 & 0.000 \\
\hline Nikkei & -0.3566378 & 0.002 & -0.3817024 & 0.000 \\
\hline MSCI & 0.5968553 & 0.000 & 0.579997 & 0.000 \\
\hline Gold & -0.1953357 & 0.081 & -0.1954244 & 0.042 \\
\hline Exchange rate & & & -0.0578233 & 0.084 \\
\hline $\mathrm{R}^{2}$ & 0.1872 & & 0.1884 & \\
\hline \multicolumn{5}{|c|}{ Multi-industry companies } \\
\hline Inflation & -4.421107 & 0.060 & -4.761113 & 0.000 \\
\hline MSCI & 0.7539504 & 0.052 & 0.4003542 & 0.075 \\
\hline Money supply & 0.2514178 & 0.100 & 0.4359759 & 0.000 \\
\hline Credit & -1.128709 & 0.026 & -1.718725 & 0.000 \\
\hline Exchange rate & & & -0.1801912 & 0.012 \\
\hline Nikkei & & & 0.4629534 & 0.079 \\
\hline $\mathrm{R}^{2}$ & 0.1455 & & 0.1634 & \\
\hline
\end{tabular}

Consumer services 


\begin{tabular}{lllll} 
Exchange rate & -0.1606574 & 0.087 & -0.189381 & 0.003 \\
Inflation & -3.850335 & 0.019 & -4.096181 & 0.000 \\
MSCI & 0.8990903 & 0.008 & 0.5476852 & 0.000 \\
Nikkei & & & 0.3993445 & 0.050 \\
$\mathrm{R}^{2}$ & 0.1482 & & 0.1567 & \\
\hline Public utility services & & & \\
Inflation & -4.773047 & 0.001 & -4.631809 & 0.000 \\
Nikkei & 0.4986593 & 0.008 & 0.2565622 & 0.046 \\
Exchange rate & & & -0.1221323 & 0.064 \\
MSCI & & & 0.4136015 & 0.067 \\
Gold & & & -0.366764 & 0.006 \\
Credit & & & -0.8246622 & 0.000 \\
$\mathrm{R}^{2}$ & & & 0.1711 & \\
\hline
\end{tabular}

The results from FEM and REM for the stock market show no difference but they are different from those of factor model. In FEM and REM for the stock market, rate of return on stocks is affected by five other risk factors besides unexpected inflation and Nikkei index. Such factors as exchange rate, gold price, interest rate, inflation, and credit growth have negative impacts on return from stocks while other factors, such as Nikkei and MCSI indexes, produce positive effects on the rate of return. These results are compliant with theories.

As shown by the results from the factor model, unexpected inflation has the greatest impact on return from stocks. When unexpected inflation rises by $1 \%$ the rate of return from stocks falls by $4.1 \%$. Impacts of other factors are much weaker. The weakest are impacts of gold price and exchange rate.

There are differences in estimates by FEM and REM for individual industries and between industries. This may be explained by the fact that those two models employ panel data and are based on the assumption that impact of each factor on stocks is the same.

Hausman test of the whole stock market produces a p-value of 1 ( $\mathrm{H}_{0}$ is not rejected), which implies that estimates by REM and FEM are unbias and convergent but REM is more efficient. We therefore decide to choose it.

Results of the Wald test for all industries and the stock market in the set of equation (1b), however, reject hypothesis $\mathrm{H}_{0}: \beta_{1 \mathrm{k}}=\beta_{2 \mathrm{k}}=\ldots \ldots=\beta_{\mathrm{Nk}}$, with $\mathrm{k}=1, \ldots, \mathrm{K}$. This implies that impacts 
of factors on rate of return from stocks are not identical. Moreover, $\mathrm{R}^{2}$ of the REM for the whole market is very small, below $19 \%$ and beta value of each factor differs remarkably over industries. We therefore reject both FEM and REM and only use the results of the factor model.

Although FEM and REM are rejected, their results also show that rate of return in all industries is affected greatly by the inflation: the strongest impacts are found in manufacturing sector and public utility services while the weakest one is on consumer goods industry. These results are rather similar to those of the factor model. Nikkei index has some impacts on rate of return from stocks of most industries, but its impacts are much weaker than that of inflation.

Although explanatory power of the factor model is higher than that of REM, it is still low (28\%). The reason could be that our model does not include some factors that may have great impacts on stock prices, such as unexpected changes in growth rate, economic policies, monetary policy, and asymmetric information. This is one of the major limitations of the research that future studies should address when the research period is long enough to obtain necessary number of observations.

\section{b. Analysis of Research Results:}

The results from the factor model show that VNIndex is only affected by unexpected inflation and Nikkei 225 index and impact of inflation is much stronger. This is not surprising because in the research period, inflation rate in Vietnam was unpredictable, which made investors lose trust in the monetary policy adopted by the SBV and Vietnamese government. In other words, Vietnamese investors are very sensitive to unexpected fluctuations in inflation rate.

Nikkei 225 index has a positive impact on VNIndex. Fluctuations in major stock exchanges in Asia produce among Vietnamese investors some expectations of similar fluctuations in Vietnamese stock market. Such expectations affect trade in stocks in an effort to gain profits if similar fluctuations take place. A forward relationship between rate of return in Vietnamese market and similar rates on Asian markets comes into existence. Moreover, fluctuations in Nikkei also reflect the regional economic situation, and therefore, this index has a positive impact on VNIndex.

Regression results for 35 stocks from six industries confirm impacts of unexpected inflation and Nikkei index on prices of most stocks.

Impact of inflation on stock prices is strong but uneven among industries and among stocks in the same industry as well. This shows itself in the following facts: 
- Stocks with high liquidity, issued by well-managed firms and free from bad effects by the recent economic recession in Vietnam only suffer slight impacts, and even no impact at all, of unexpected inflation. GIL, for example, produced stable and high dividends although its profits fluctuated wildly over the past few years. Price of this stock rose steadily in the past three years and it is now ranked among blue chips because it has a high liquidity and is not much affected by inflation. PVD and VNM stocks also have high liquidity because these firms achieved high growth rates of sales and profits, and are not badly affected by the economic recession. It is therefore not surprising that prices of PVD and VNM are not affected by inflation.

- Stocks of companies in trouble (suffering losses, paying small dividends, or being put in a warning list) usually witness falls in prices and liquidity, and they are almost free from effects of unexpected inflation. Stock LAF for example suffers from poor performance and prolonged loss. Its unordinary activities force stock exchange authorities to put it in the warning list. As for stock SAV, its dividend and profit have fallen for the past five years and its price was falling (to VND6,900 at the end of April 2013).

Generally, except for PVD, stocks from manufacturing sector and public utility services are affected greatly by unexpected inflation with most of their beta coefficients varying between 4 and 5 .

- Two thirds of stocks from consumer service companies have beta coefficients of inflation of 3.5, a pretty low level in comparison with stocks from other industries.

- Consumer goods companies suffer weaker impacts of inflation compared with companies in other industries, and stocks of four companies are free from impact of unexpected inflation.

- Impacts of inflation on agriculture, forestry and fisheries are dispersed. Their beta coefficients vary between 3.6 and 5.2 (not including the case of LAF).

However, the limited source of data reduces the number of surveyed stocks in each industry, which makes estimates of beta coefficients of inflation less representative.

Impacts of Nikkei index on prices of stocks in Vietnam are much weaker than those of unexpected inflation. Beta coefficients for Nikkei of most stocks are smaller than 1. Two out of five stocks (SFC and SJD) from public utility services are even free from such impacts; and the weakest impact of Nikkei is also found in this industry. This is understandable because this industry rarely feels effects from fluctuations in regional economy. Nikkei impacts on stock prices in Vietnam are less dispersed than those of inflation with beta coefficients varying from 0.36 to 1.4. Agriculture-forestry-fisheries sector and consumer goods industry have more dispersed beta coefficients while this coefficient of the manufacturing sector is pretty even. 


\section{CONCLUSIONS AND RECOMMENDATIONS}

\section{a. Conclusions:}

The research clarifies methods and process of estimating impacts of factors and applies them to the Vietnam stock market. The results show that impacts of factors on rate of return on stocks differ among industries and among companies within the same industry. This implies that REM and FEM cannot be used for estimating such impacts on rate of return on stocks.

Results of factor model show that rate on return on stocks is affected by unexpected inflation and Japanese Nikkei 225 index, and the impacts of the former are much stronger than those of the latter.

Stocks from companies with sound financial strength and high profit usually suffer weak impacts but stocks with poor liquidity from companies included in the warning list are also free from impacts of inflation. Stocks from manufacturing sector and public utility services suffer the strongest impacts of unexpected inflation, but the public utility services suffer the least impact of Nikkei index.

\section{b. Recommendations:}

Research results lead to the following recommendations for investors:

Firstly, investors should be careful when making investment decision during periods of high inflation or wild fluctuations and avoid stocks with high beta coefficients for inflation. Moreover, investors should consider business performance of companies before making investment because many of them are rarely affected by external environment.

Secondly, VNM and PVD are two reliable stocks in this period and free from impacts of inflation. Investors can consider buying them. GIL is also relatively reliable and could be seen as a right choice because of its low beta coefficient for inflation.

Thirdly, investors should be careful when considering buying stocks from manufacturing sector and public utility services, especially at present when inflation rate fluctuates unpredictably, because those stocks are affected greatly by inflation.

Fourthly, top priorities could be given to stocks from companies with sound performance and good financial strength when inflation becomes unpredictable.

Fifthly, investor should pay some attention to impacts of regional economy that are reflected in Nikkei index.

In controlling and stabilizing the stock market, authorities should pay full attention to inflation in order to facilitate development of the stock market and the whole economy as well. 
State Securities Commission should improve quality of information and help securities companies make better predictions of inflation in order to avoid market panic and serious recession as that of 2008 .

By gathering timely information about fluctuations in foreign stock markets, the State Securities Commission can produce early predictions and make plan to address possible fluctuations in order to stabilize the domestic stock market

\section{References}

Chen, N.-F., R. Roll \& S. Ross (1986), "Economic Forces and the Stock Market”, Journal of Business, Vol. 59, Issue 3, 383-403.

Gan C., M. Lee, H. Yong \& J. Zhang (2006), "Macroeconomic Variables and Stock Market Interactions: New Zealand Evidence", Investment Management and Financial Innovations, Volume 3, Issue 4.

Mohammad S.D., Syed Iqbal Hussain Naqvi, Irfan Lal \& Saba Zehra (2012), “Arbitrage Price Theory (APT) and Karachi Stock Exchange (KSE)”, Asian Social Science, Vol. 8, No 2.

Mukhopadhyay, D. \& N. Sarkar (2003), "Stock Return and Macroeconomic Fundamentals in ModelSpecification Framework: Evidence from Indian Stock Market", Indian Statistical Institute, Economic Research Unit, ERU 2003-05. Discussion Paper, January 2003, 1-28.

Nguyễn Thu Hiền \& Đinh Thị Hồng Loan, "Tác động của lạm phát lên suất sinh lợi đầu tư cổ phiếu - Nhận định từ nghiên cứu dữ liệu thị trường chứng khoán Việt Nam”, Phát Triển Kinh Tế, No 224 (June, 2009), 11-18.

Ross, Stephen A. (1976), “An Arbitrage Theory of Capital Asset Pricing”, Journal of Economic Theory, 13: 341-360.

Trần Minh Ngọc Diễm (2008), “Úng dụng các lý thuyết tài chính hiện đại trong việc đo lường rủi ro của các chứng khoán niêm yết tại Sở giao dịch chứng khoán thành phố Hồ Chí Minh”, an unpublished Master dissertation. 